\title{
UPAYA MENINGKATKAN MUTU PEMBELAJARAN PAI DAN BUDI PEKERTI MELALUI COOPERATIVE LEARNING MODEL STUDENT TEAMS ACHIEMEMENT DIVISION
}

\author{
ERMI INAYAH \\ Sekolah Dasar Negeri Singasari \\ e-mail: ermiinayah.gurusd@gmail.com
}

\begin{abstract}
ABSTRAK
Penelitian ini bertujuan untuk meningkatkan mutu pembelajaran Pendidikan Agama Islam dan Budi Pekerti. Pembelajaran Pendidikan Agama Islam dan Budi Pekerti dengan penerapan metode Cooperative Learning model STAD diharapkan dapat meningkatkan prestasi belajar siswa sekaligus minat belajar mata pelajaran Pendidikan Agama Islam dan Budi Pekerti. Penelitian ini adalah penelitian tindakan kelas yang dilaksanakan 2 siklus. Subyek dari penelitian ini adalah siswa kelas III SDN Singasari dengan jumlah siswa 28 anak. Hasil penelitian menunjukkan bahwa upaya untuk meningkatkan mutu belajar PAI dan Budi Pekerti berhasil dengan baik dan minat belajar PAI dan budi Pekerti. Mutu pembelajaran terlihat pada perubahan kegiatan pembelajaran di kelas.Pada siklus 1 kegiatan diskusi ternyata di dominasi oleh siswa yang pandai. Pada siklus 2, tampak keberanian siswa untuk bertanya dan menyampaikan pendapatnya sangat besar.Pada siklus 1 tidak ada satupun yang mendapat penghargaan kelompok, tetapi pada siklus 2 semua kelompok mendapat penghargaan yang tinggi (Super team). Peningkatan prestasi belajar ditunjukkan dengan keaktifan siswa, juga ditunjukkan dengan ketuntasan belajar secara klasikal naik dari 7,14\% menjadi 85,20\%, sedangkan rata-rata prestasi belajar siswa naik dari 64,67 pada siklus I menjadi 82,37 pada siklus 2
\end{abstract}

Kata Kunci: Cooperative Learning, STAD, mutu pembelajaran

\section{ABSTRACT}

This study aims to improve the quality of learning Islamic Religious Education and Morals. Learning Islamic Religious Education and Morals with the application of the STAD Cooperative Learning method is expected to improve student achievement as well as interest in learning subjects of Islamic Religious Education and Character Education.This research is a classroom action research conducted in 2 cycles. The subjects of this study were third grade students of SDN Singasari with a total of 28 students. The results showed that efforts to improve the quality of learning PAI dan Budi Pekerti were successfull and interest in learning PAI and carácter was Good. The quality of learning can be seen in the changes in learning activities in the classroom. In cycle 1, the discusión activities were dominated by Smart students. In cycle 2 , it appears that the students' courage to ask questions and express their opinions is very large. In cycle 1, none of them received group awards, but in cycle 2 all groups received high award ( Super team ). The increase in learning achievement is indicated by the activeness of students, also indicated by classical learning mastery which rose from $7.14 \%$ to $85.20 \%$, while the average student achievement rose from 64.67 in the first cycle to 82.37 in the second cycle. Keywords: Cooperative Learning, STAD, quality of learning

\section{PENDAHULUAN}

Pendidikan Agama Islam dan Budi Pekerti merupakan salah satu mata pelajaran yang wajib diberikan di Sekolah Dasar (SD). Pendidikan Agama Islam dan Budi Pekerti merupakan salah satu pembelajaran yang menarik untuk dipelajari karena berhubungan dengan hati dan perasaan yang dirasakan dari dalam tubuh manusia, diantaranya perasaan tenang, senang dan nyaman. Untuk menyampaikan semua ini membutuhkan metode yang tidak membosankan siswa.Hal ini menuntut guru untuk melakukan"transfer of knowledge"dengan teknologi informasi dan media pembelajaran yang bervariasi serta mengarahkan siswa aktif. Berdasarkan 


\section{STRATEGY : Jurnal Inovasi Strategi dan Model Pembelajaran Vol 2. No 1. Januari Tahun 2021 e-ISSN : 2798-5466 P-ISSN : 2798-5725}

hal tersebut, siswa dituntut untuk berperan aktif dalam menggali pengetahuannya sendiri baik melalui pengamatan atau penyelidikan maupun pemberian pengalaman pembelajaran secara langsung bagi siswa.

Melihat data rendahnya tingkat aktivitas dan hasil belajar siswa khususnya dalam mata pelajaran Pendidikan Agama Islam dan Budi Pekerti, maka guru perlu memperbaiki proses pembelajaran di sekolah dengan menggunakan model pembelajaran yang sesuai dengan karakteristik siswa dan mata pelajaran Pendidikan Agama Islam dan Budi Pekerti. Proses pembelajaran sebaiknya lebih banyak melibatkan siswa, sehingga siswa akan aktif dan semangat dalam mengikuti pembelajaran.Berdasarkan hasil observasi yang dilakukan di SDN Singasari di temukan bahwa aktifitas dan hasil belajar siswa terutama dalam mata pelajaran Pendidikan Agama Islam dan Budi Pekerti masih relatif rendah. Dari hasil perolehan data nilai, pada mata pelajaran Pendidikan Agama Islam dan Budi Pekerti kelas III SDN Singasari menyatakan bahwa hasil belajar Pendidikan Agama Islam dan Budi Pekerti kelas III masih di bawah kriteria ketuntasan minimal (KKM) yang di tentukan sekolah yaitu 80 hanya dapat dituntaskan oleh 10 siswa atau 7,14\% dari jumlah 28 siswa.Hal tersebut di sebabkan oleh beberapa faktor diantaranya kurang konsentrasinya siswa dalam pembelajaran, kreatifitas guru dalam pembelajaran Pendidikan Agama Islam dan Budi Pekerti masih kurang, oleh karena itu guru perlu mengimplementasikan model pembelajaran lain yang dapat meningkatkan minat, motivasi dan hasil belajar siswa. Salah satu model pembelajaran yang dapat diimplementasikan adalah model pembelajaran Student Teams Achievement Divison (STAD) (Nikmah, dkk, 2016).

Model pembelajaran Student Teams Achievement Divison (selanjutnya di debut dengan STAD) merupakan pendekatan Cooperative Learning yang dapat meningkatkan aktivitas dan interaksi siswa, sehingga dapat saling memotivasi dan membantu dalam proses penguasaan materi pelajaran untuk mendapatkan hasil belajar yang maksimal (Kusuma, 2017). Lie (2004) juga mengatakan Cooperative Learning atau pembelajaran Gotong Royong adalah sistem pengajaran yang memberi kesempatan kepada anak didik untuk bekerja sama dengan sesama siswa dalam tugas-tugas yang terstruktur. Metode Cooperative Learning membutuhkan adanya kerja sama antar siswa untuk mencapai tujuannya dengan memperhatiakan prinsip pembelajaran yang baik, sebagaimana yang di kemukakan oleh Slavin (1999): bahwa semua metode pembelajaran kooperatif memberi ide bahwa siswa bekerja sama untuk belajar dan bertanggung jawab terhadap kelompok belajarnya sebaik mereka sendiri, disamping untuk menunjukkan kerja sama. Metode kelompok belajar menekankan pada penggunaan pencapaian dan kesuksesan kelompok, yang hanya dapat dicapai jika semua anggota kelompok mempelajari obyek menjadi suatu pengajaran. Itu artinya, dalam kelompok belajar tugas siswa tidak untuk melakukan sesuatu hal sebagai kelompok tetapi untuk mempelajari sebagai sebuah kelompok.

Alasan pemilihan model pembelajaran STAD ini diantaranya adalah dengan cooperative Learning ini tujuan pembelajaran yang di capai tidak hanya mencakup aspek akademik, namun juga mempunyai dampak terhadap aspek sosial (non akademik) dalam bentuk kerjasama, latihan memimpin dan latihan berorganisasi. Metode Cooperative Learning ini secara faktual merupakan metode yang dapat memberikan kesempatan yang adil dan merata kepada seluruh anggota kelompok untuk aktif partisipatif dalam pemecahan masalah. Dalam Cooperative Learning ini tidak ada siswa yang mendominasi kesempatan guna mengemukakan ide/gagasan dalam pemecahan masalah.

Dalam teknik Cooperative Learning ini, para siswa menerima informasi melalui ceramah, film-film, bacaan-bacaan dan sebagainya kemudian menerima untuk melengkapi kertas kerja tim empat. Tim dibentuk oleh guru dalam bentuk heterogen dengan dasar mendahulukan kemampuan, peringkat, jenis kelamin, latar belakang bahasa dan faktor lain yang di tentukan instruktur. Kertas kerja mungkin berisi tentang masalah pelajaran, pemecahan masalah atau pertanyaan lain. Sekali lagi, semua anggota bersepakat untuj melengkapi tugas dan ketrampilan yang di nilai dalam kertas kerja, sampai dipanggil kembali instruktur. Dalam ujian lisan anggota kelompok dalam bagaimana memecahkan masalah-masalah kertas kerja, 
instruktur mungkin satu atau semua anggota tim tentang pengujian individu oleh anggota tim ( tanggung jawab individu ). Melibatkan "kompetisi" antar kelompok siswa dikelompokkan secara secara beragam berdasarkan kemampuan, gender, ras dan etnis. Perolehan nilai kuis setiap anggota menentukan skor yang diperoleh oleh kelompok mereka. Jadi setiap anggota kelompok harus berusaha memperoleh nilai maksimal dalam kuis, jika kelompok mereka ingin mendapatkan skor yang tinggi. Menurut Trianto (2007), pembelajaran tipe STAD ini merupakan salah satu tipe dari model pembelajaran kooperatif dengan menggunakan kelompok-kelompok kecil dengan jumlah anggota tiap kelompok 4-5 orang siswa secara heterogen. Diawali dengan penyampaian tujuan pembelajaran, penyampaian materi, kegiatan kelompok, kuis, dan penghargaan kelompok.

Untuk pelaksanaan cooperative learning model STAD, disusun langkah-langkah pokok sebagai berikut :

1.) Pembagian tugas

2.) Pemberian lembar ahli

3.) Mengadakan diskusi

4.) Mengadakan kuis

Setelah kuis dilakukan, maka dilakukan perhitungan skor peningkatan individu dan skor kelompok. Skor individu setiap kelompok memberi sumbangan pada skor kelompok, berdasarkan rentang skor yang diperoleh pada nilai sebelumnya dengan skor terakhir.

Ide yang mendasari perhitungan nilai peningkatan individu ini adalah untuk memberikan suatu tujuan prestasi yang dapat dicapai tiap siswa dan dalam hal ini hanya dapat diraih jika siswa tersebut berusaha lebih keras dan memperoleh prestasi yang lebih baik dari apa yang diperoleh sebelumnya(Slavin,1995).

Mekanisme perhitungan skor peningkatan individu adalah sebagai berikut :

1. Setiap siswa mendapat nilai dasar yang merupakan rerata kuis atau ulangan harian pada pokok bahasan sebelumnya.

2. Setelah siswa mengerjakan kuis, nilai kuis tersebut dibandingkan dengan nilai dasar mereka.

3. Besarnya nilai perkembangan individu ditentukan berdasarkan suatu kriteria tertentu. Acuan kriteria peningkatan nilai individu dapat dilihat pada tabel berikut :

Tabel 1. Kriteria Peningkatan nilai individu dalam teknik STAD

\begin{tabular}{|l|c|}
\hline \multicolumn{1}{|c|}{ Kriteria } & Nilai Peningkatan \\
\hline Lebih dari 10 poin di bawah nilai awal & 5 poin \\
\hline 10 poin s/d 1 poin di bawah nilai awal & 10 poin \\
\hline Nilai awal s/d 10 poin di atasnya & 20 poin \\
\hline Lebih dari 10 poin di atas nilai awal & 30 poin \\
\hline Nilai sempurna (tak berdasarkan nilai awal) & 30 poin \\
\hline
\end{tabular}

Berdasarkan nilai rata-rata peningkatan individu seluruh anggota kelompok, ditetapkan nilai kelompok . Guru memberikan penghargaan kepada kelompok sesuai dengan nilai yang dicapai. Penghargaan ini dapat berupa pijian, hadiah, atau bentuk lain sebagai penghargaan kelompok. Slavin menetapkan kriteria penghargaan kelompok sebagai berikut :

Tabel 2. Kriteria Penghargaan kelompok dalam model STAD

\begin{tabular}{|c|c|}
\hline Nilai Kelompok & Kriteria Penghargaan \\
\hline $15 \leq$ Nilai $<20$ & Kelompok baik ( Good Team ) \\
\hline $20 \leq$ Nilai $<25$ & Kelompok hebat ( Great Team ) \\
\hline $25 \leq$ Nilai $<30$ & Kelompok super ( Super Team ) \\
\hline
\end{tabular}

Tujuan yang bisa diambil dalam penelitian ini adalah untuk mengetahui aktivitas belajar siswa dan hasil belajar siswa dalam penerapan model pembelajaran kooperatif tipe STAD pada mata pelajaran Pendidikan Agama Islam dan Budi Pekerti di kelas III SDN Singasari. 


\section{METODE PENELITIAN}

Penelitian ini dilaksanakan di kelas III SDN Singasari yang berlokasi di Jalan Raya Desa Singasari, pada semester genap tahun pelajaran 2018/2019. Subjek penelitian ini adalah siswasiswi kelas III di SDN Singasari pada semester genap tahun pelajaran 2018/2019. Dimana jumlah siswa di kelas III adalah 28 siswa, yang terdiri dari 17 siswi perempuan dan 11 siswa laki-laki.Objek dalam penelitian ini adalah aktivitas belajar siswa dan hasil belajar siswa dengan menggunakan model pembelajaran kooperatif tipe STAD. Penelitian ini merupakan penelitian tindakan kelas (PTK), dalam pelaksanaannya memakai siklus. Setiap siklus terdiri dari 4 tahapan yaitu :
1.) Tahap Perencanaan Tindakan
2.) Tahap Pelaksanaan Tindakan
3.) Tahap Observasi Tindakan, dan
4.) Tahap Refleksi

Dalam penelitian ini, teknik pengumpulan data yang digunakan yaitu:
1.) Pengamatan
2.) Tes(Kuis)
3.) Dokumentasi
4.) Angket
5.) Wawancara

Indikator ketuntasan hasil belajar siswa mengacu pada kriteria belajar tuntas sebagai berikut :

1. Siswa telah belajar tuntas, jika mencapai $75 \%$ atau nilai 75 dari nilai maksimal

2. Kelas telah belajar tuntas, jika terdapat $85 \%$ siswa yang telah belajar tuntas.

Apabila kelas belum mencapai ketuntasan belajar, maka penelitian tindakan dilanjutkan pada siklus berikutnya. Tindakan yang dipilih pada siklus ini direncanakan berdasarkan hasil refleksi dari tindakan pada siklus sebelumnya.

\section{HASIL DAN PEMBAHASAN}

\section{Hasil}

Penutup pembelajaran siklus 1 dilaksanakan pada pertemuan ke 2. Siswa mengerjakan kuis secara individu dalam waktu 20 menit. Penilaian kuis dilakukan bersama-sama dengan siswa dan guru memberikan pedoman penilaiannya. Selain itu guru juga memberikan lembar penilaian untung menghitung poin peningkatan individu dan menentukan nilai kelompok.

Tabel 3. Hasil Nilai Individu dan Kelompok pada Siklus 1

\begin{tabular}{|c|l|c|c|c|c|}
\hline NO & NAMA & $\begin{array}{c}\text { NAMA } \\
\text { KELOMPOK } \\
\text { ASAL }\end{array}$ & $\begin{array}{c}\text { NILAI } \\
\text { AWAL }\end{array}$ & $\begin{array}{c}\text { NILAI } \\
\text { KUIS }\end{array}$ & $\begin{array}{c}\text { POIN } \\
\text { PENINGKATAN } \\
\text { INDIVIDU }\end{array}$ \\
\hline 1 & Adi Aminulloh & A & 63 & 65 & 20 \\
\hline 2 & $\begin{array}{l}\text { Alfian Sarah Saeed Al } \\
\text { Mesmari }\end{array}$ & A & 90 & 70 & 5 \\
\hline 3 & Alin Fajar Aryanto & A & 80 & 65 & 5 \\
\hline 4 & Almas Dhiya Pamungkas & A & 77 & 60 & 5 \\
\hline & & \multicolumn{4}{|c|}{ Jumlah poin peningkatan nilai } \\
individu \\
\hline
\end{tabular}


STRATEGY : Jurnal Inovasi Strategi dan Model Pembelajaran

Vol 2. No 1. Januari Tahun 2021 e-ISSN : 2798-5466 P-ISSN : 2798-5725

\begin{tabular}{|c|c|c|c|c|c|}
\hline 8 & Fandi Malobi & $\mathrm{B}$ & 63 & 60 & 10 \\
\hline & & \multicolumn{3}{|c|}{$\begin{array}{l}\text { Jumlah poin peningkatan nilai } \\
\text { individu }\end{array}$} & 80 \\
\hline & & & \multicolumn{2}{|c|}{ Nilai kelompok } & 20 \\
\hline & & & \multicolumn{2}{|c|}{$\begin{array}{c}\text { Penghargaan } \\
\text { kelompok }\end{array}$} & GREAN TEAM \\
\hline 9 & Fathian Azani Pratama & $\mathrm{C}$ & 80 & 65 & 5 \\
\hline 10 & Febi Nurul Hikmah & $\mathrm{C}$ & 80 & 65 & 5 \\
\hline 11 & Vika Riskia Putri & $\mathrm{C}$ & & & \\
\hline \multirow[t]{4}{*}{12} & Firzatul Anida & $\mathrm{C}$ & 47 & 65 & 30 \\
\hline & & \multicolumn{3}{|c|}{$\begin{array}{l}\text { Jumlah poin peningkatan nilai } \\
\text { individu }\end{array}$} & 40 \\
\hline & & & \multicolumn{2}{|c|}{ Nilai kelompok } & 10 \\
\hline & & & \multicolumn{2}{|c|}{$\begin{array}{c}\text { Penghargaan } \\
\text { kelompok }\end{array}$} & TIDAK ADA \\
\hline 13 & Fithra Ikrima Aulia & $\mathrm{D}$ & 67 & 52 & 5 \\
\hline 14 & Khayuna Zaida Rizqina & $\mathrm{D}$ & 87 & 72 & 5 \\
\hline 15 & Mhallaq Nancy Pradela & $\mathrm{D}$ & 83 & 60 & 5 \\
\hline \multirow[t]{4}{*}{16} & Mugi Eka Prawira & $\mathrm{D}$ & 50 & 60 & 10 \\
\hline & & \multicolumn{3}{|c|}{$\begin{array}{l}\text { Jumlah poin peningkatan nilai } \\
\text { individu }\end{array}$} & 25 \\
\hline & & & \multicolumn{2}{|c|}{ Nilai kelompok } & 6,25 \\
\hline & & & \multicolumn{2}{|c|}{$\begin{array}{l}\text { Penghargaan } \\
\text { kelompok }\end{array}$} & TIDAK ADA \\
\hline 17 & Nabila Salsa Ramadhani & $\mathrm{E}$ & 88 & 76 & 5 \\
\hline 18 & Natania Belva Islamia & $\mathrm{E}$ & 85 & 64 & 5 \\
\hline 19 & Resya Armi Al Fatih & $\mathrm{E}$ & 71 & 60 & 5 \\
\hline \multirow[t]{4}{*}{20} & Umu Salamah & $\mathrm{E}$ & 61 & 64 & 20 \\
\hline & & \multicolumn{3}{|c|}{$\begin{array}{l}\text { Jumlah poin peningkatan nilai } \\
\text { individu }\end{array}$} & 35 \\
\hline & & & \multicolumn{2}{|c|}{ Nilai kelompok } & 8,75 \\
\hline & & & \multicolumn{2}{|c|}{$\begin{array}{l}\text { Penghargaan } \\
\text { kelompok }\end{array}$} & TIDAK ADA \\
\hline 21 & Rival Noor Rasha & $\mathrm{F}$ & 57 & 46 & 5 \\
\hline 22 & Satriyo Adiyansyah & $\mathrm{F}$ & 77 & 60 & 5 \\
\hline 23 & Syafira Febri Utami & $\mathrm{F}$ & 78 & 44 & 5 \\
\hline \multirow[t]{4}{*}{24} & Vizay Kimlay Al Hadaf & $\mathrm{F}$ & 63 & 50 & 5 \\
\hline & & \multicolumn{3}{|c|}{$\begin{array}{l}\text { Jumlah poin peningkatan nilai } \\
\text { individu }\end{array}$} & 20 \\
\hline & & & \multicolumn{2}{|c|}{ Nilai kelompok } & 6,67 \\
\hline & & & \multicolumn{2}{|c|}{$\begin{array}{l}\text { Penghargaan } \\
\text { kelompok }\end{array}$} & TIDAK ADA \\
\hline 25 & Zahra Adelia & G & 75 & 72 & 10 \\
\hline 26 & Zaki Aprianto & G & 68 & 66 & 10 \\
\hline 27 & Wafa Ghaziya Adila & G & 92 & 66 & 5 \\
\hline \multirow[t]{2}{*}{28} & Muhammad Kholil & G & 76 & 80 & 20 \\
\hline & & \multicolumn{3}{|c|}{$\begin{array}{l}\text { Jumlah poin peningkatan nilai } \\
\text { individu }\end{array}$} & 45 \\
\hline
\end{tabular}


STRATEGY : Jurnal Inovasi Strategi dan Model Pembelajaran

Vol 2. No 1. Januari Tahun 2021 e-ISSN : 2798-5466 P-ISSN : 2798-5725

\begin{tabular}{|c|c|c|c|}
\cline { 3 - 4 } & & Nilai kelompok & 11,25 \\
\hline & & $\begin{array}{c}\text { Penghargaan } \\
\text { kelompok }\end{array}$ & TIDAK ADA \\
\hline
\end{tabular}

Penutup pembelajaran siklus 2 dilaksanakan pada pertemuan ke 3. Siswa mengerjakan kuis secara individu dalam waktu 20 menit. Penilaian kuis dilakukan bersama-sama dengan siswa. Kemudian guru memberikan pedoman penilaiannya. Selain itu guru juga memberikan lembar penilaian untung menghitung poin peningkatan individu dan menentukan nilai kelompok. Guru memberikan reward kepada kelompok yang berprestasi.

Tabel 4. Hasil Analisis Nilai Individu dan Kelompok pada Siklus 2

\begin{tabular}{|c|c|c|c|c|c|}
\hline NO & NAMA & $\begin{array}{c}\text { NAMA } \\
\text { KELOMPOK } \\
\text { ASAL } \\
\end{array}$ & $\begin{array}{l}\text { NILAI } \\
\text { AWAL }\end{array}$ & $\begin{array}{l}\text { NILAI } \\
\text { KUIS }\end{array}$ & $\begin{array}{c}\text { POIN } \\
\text { PENINGKATAN } \\
\text { INDIVIDU } \\
\end{array}$ \\
\hline 1 & Adi Aminulloh & A & 58 & 92 & 30 \\
\hline 2 & $\begin{array}{l}\text { Alfian Sarah Saeed Al } \\
\text { Mesmari }\end{array}$ & A & 76 & 84 & 30 \\
\hline 3 & Alin Fajar Aryanto & A & 68 & 76 & 30 \\
\hline \multirow[t]{4}{*}{4} & Almas Dhiya Pamungkas & A & 60 & 92 & 30 \\
\hline & & \multicolumn{3}{|c|}{$\begin{array}{l}\text { Jumlah poin peningkatan nilai } \\
\text { individu }\end{array}$} & 120 \\
\hline & & & \multicolumn{2}{|c|}{ Nilai kelompok } & 30 \\
\hline & & & \multicolumn{2}{|c|}{$\begin{array}{l}\text { Penghargaan } \\
\text { kelompok }\end{array}$} & SUPER TEAM \\
\hline 5 & Atika Sulis Rahmadani & $\mathrm{B}$ & 60 & 84 & 30 \\
\hline 6 & Ayda Rafeyfa Asyla & $\mathrm{B}$ & 72 & 80 & 20 \\
\hline 7 & Chafidza Nur Azizah & $\mathrm{B}$ & 52 & 84 & 30 \\
\hline \multirow[t]{4}{*}{8} & Fandi Malobi & $\mathrm{B}$ & 52 & 84 & 30 \\
\hline & & \multicolumn{3}{|c|}{$\begin{array}{l}\text { Jumlah poin peningkatan nilai } \\
\text { individu }\end{array}$} & 110 \\
\hline & & & \multicolumn{2}{|c|}{ Nilai kelompok } & 27,5 \\
\hline & & & \multicolumn{2}{|c|}{$\begin{array}{c}\text { Penghargaan } \\
\text { kelompok }\end{array}$} & SUPER TEAM \\
\hline 9 & Fathian Azani Pratama & $\mathrm{C}$ & 60 & 80 & 30 \\
\hline 10 & Febi Nurul Hikmah & $\mathrm{C}$ & 80 & 88 & 20 \\
\hline 11 & Vika Riskia Putri & $\mathrm{C}$ & 56 & 80 & 30 \\
\hline \multirow[t]{4}{*}{12} & Firzatul Anida & $\mathrm{C}$ & 60 & 80 & 30 \\
\hline & & \multicolumn{3}{|c|}{$\begin{array}{l}\text { Jumlah poin peningkatan nilai } \\
\text { individu }\end{array}$} & 110 \\
\hline & & & \multicolumn{2}{|c|}{ Nilai kelompok } & 27,5 \\
\hline & & & \multicolumn{2}{|c|}{$\begin{array}{l}\text { Penghargaan } \\
\text { kelompok }\end{array}$} & SUPER TEAM \\
\hline 13 & Fithra Ikrima Aulia & $\mathrm{D}$ & 60 & 80 & 30 \\
\hline 14 & Khayuna Zaida Rizqina & $\mathrm{D}$ & 72 & 80 & 20 \\
\hline 15 & Mhallaq Nancy Pradela & $\mathrm{D}$ & 60 & 88 & 30 \\
\hline \multirow[t]{2}{*}{16} & Mugi Eka Prawira & $\mathrm{D}$ & 52 & 88 & 30 \\
\hline & & \multicolumn{3}{|c|}{$\begin{array}{l}\text { Jumlah poin peningkatan nilai } \\
\text { individu }\end{array}$} & 110 \\
\hline
\end{tabular}


STRATEGY : Jurnal Inovasi Strategi dan Model Pembelajaran

Vol 2. No 1. Januari Tahun 2021 e-ISSN : 2798-5466 P-ISSN : 2798-5725

\begin{tabular}{|c|c|c|c|c|c|}
\hline & & \multirow[b]{3}{*}{$\mathrm{E}$} & \multirow{2}{*}{\multicolumn{2}{|c|}{$\begin{array}{c}\text { Nilai kelompok } \\
\text { Penghargaan } \\
\text { kelompok }\end{array}$}} & \multirow{3}{*}{$\begin{array}{c}\text { SUPER TEAM } \\
5 \\
\end{array}$} \\
\hline & \multirow[b]{2}{*}{ Nabila Salsa Ramadhani } & & & & \\
\hline 17 & & & 76 & 64 & \\
\hline 18 & Natania Belva Islamia & $\mathrm{E}$ & 64 & 80 & 30 \\
\hline 19 & Resya Armi Al Fatih & $\mathrm{E}$ & 64 & 76 & 30 \\
\hline 20 & Umu Salamah & $\mathrm{E}$ & 60 & 88 & 30 \\
\hline & & \multicolumn{3}{|c|}{$\begin{array}{l}\text { Jumlah poin peningkatan nilai } \\
\text { individu }\end{array}$} & 95 \\
\hline & & & \multicolumn{2}{|c|}{ Nilai kelompok } & 23,75 \\
\hline & & & \multicolumn{2}{|c|}{$\begin{array}{l}\text { Penghargaan } \\
\text { kelompok }\end{array}$} & GREAT TEAM \\
\hline 21 & Rival Noor Rasha & $\mathrm{F}$ & 44 & 76 & 20 \\
\hline 22 & Satriyo Adiyansyah & $\mathrm{F}$ & 50 & 84 & 20 \\
\hline 23 & Syafira Febri Utami & $\mathrm{F}$ & 60 & 80 & 30 \\
\hline \multirow[t]{4}{*}{24} & Vizay Kimlay Al Hadaf & $\mathrm{F}$ & 46 & 88 & 30 \\
\hline & & \multicolumn{3}{|c|}{$\begin{array}{l}\text { Jumlah poin peningkatan nilai } \\
\text { individu }\end{array}$} & 100 \\
\hline & & & \multicolumn{2}{|c|}{ Nilai kelompok } & 25,00 \\
\hline & & & \multicolumn{2}{|c|}{$\begin{array}{l}\text { Penghargaan } \\
\text { kelompok }\end{array}$} & SUPER TEAM \\
\hline 25 & Zahra Adelia & $\mathrm{G}$ & 72 & 80 & 20 \\
\hline 26 & Zaki Aprianto & $\mathrm{G}$ & 66 & 0 & 0 \\
\hline 27 & Wafa Ghaziya Adila & G & 80 & 88 & 20 \\
\hline \multirow[t]{4}{*}{28} & Muhammad Kholil & $\mathrm{G}$ & 66 & 80 & 30 \\
\hline & & \multicolumn{3}{|c|}{$\begin{array}{l}\text { Jumlah poin peningkatan nilai } \\
\text { individu }\end{array}$} & 70 \\
\hline & & & \multicolumn{2}{|c|}{ Nilai kelompok } & 23,33 \\
\hline & & & \multicolumn{2}{|c|}{$\begin{array}{l}\text { Penghargaan } \\
\text { kelompok }\end{array}$} & GREAT TEAM \\
\hline
\end{tabular}

\section{Pembahasan}

Sebelum pembelajaran telah dilaksanakan upaya pengamatan kepada siswa tentang minat belajar dan prestasi belajar, dilanjutkan sosialisasi tentang Cooperative Learning dengan model STAD. Sesudah dilaksanakan apersepsi, kemudian siswa dibagi dalam kelompok, yang disebut kelompok asal terdiri dari 4 siswa. Pada siklus 1, siswa masih terasa asing dengan metode Cooperative Learning dengan model STAD. Siswa terlihat canggung dan agak bingung. Namun dengan bimbingan guru yang telaten dan serius, akhirnya siswa dalam melaksanakan pembelajaran dengan baik. Meskipun agak lambat, siswa dapat merasakan penerapan metode Cooperative Learning, sehingga kemudian siswa terlihat senang dengan model STAD ini di tandai dengan kerja sama dalam kelompok, walaupun sebagian kelompok agak kecewa, karena penghargaan kelompok ada yang kosong atau tidak ada penghargaan.

Pada siklus 2 ini, aktifitas siswa secara individu maupun kelompok tampak meningkat. Indikator peningkatan aktifitas pembelajaran diketahui dari serius saat mengerjakan tugas dan ekspresi semangat saat diskusi kelompok. Dalam menjawab sanggahan kelompok lain dalam diskusi kelas, siswa menggunakan beberapa buku referensi, dan internet sebagai bekal untuk dapat menjelaskan dan melaksanakan tanggung jawabnya. Melalui kerja sama yang kompak, mereka ingin agar nilai individu naik untuk dapat menyumbang kepada kelompoknya, sehingga penghargaan kelompok juga menjadi naik. Dilihat dari segi perkembangan kognitif,model 
pembelajaran STAD dapat meningkatkan hasil belajar siswa. Hal ini dapat dibuktikan dengan hasil penelitian yang lain seperti Firdaus (2016) yang menguju pengaruh model pembelajaran STAD terhadap hasil belajar matematika pada materi operasi hitung bentuk aljabar di SMP Negeri 1 Kendawan menunjukkan bahwa model pembelajaran STAD dapat meningkatkan hasil belajar matematika siswa. Hal serupa juga pernah dilakukan oleh mirhasli (2021) yang menunjukkan bahwa implementasi model pembelajaran STAD dapat meningkatkan hasil belajar materi matriks di SMAN 4 Tebo. bawah ini :

Dalam penelitian ini, penghargaan kelompok yang di peroleh dapat dilihat pada tabel di

Tabel 5. Penghargaan Kelompok

\begin{tabular}{|c|c|c|c|}
\hline NO & NAMA KELOMPOK & SIKLUS 1 & SIKLUS 2 \\
\hline 1 & A & TIDAK ADA & SUPER TEAM \\
\hline 2 & $\mathrm{~B}$ & TIDAK ADA & SUPER TEAM \\
\hline 3 & $\mathrm{C}$ & TIDAK ADA & SUPER TEAM \\
\hline 4 & $\mathrm{D}$ & TIDAK ADA & SUPER TEAM \\
\hline 5 & $\mathrm{E}$ & TIDAK ADA & TREAT TEAM \\
\hline 6 & $\mathrm{~F}$ & TIDAK ADA & SUPER TEAM \\
\hline 7 & $\mathrm{G}$ & GREAT TEAM \\
\hline
\end{tabular}

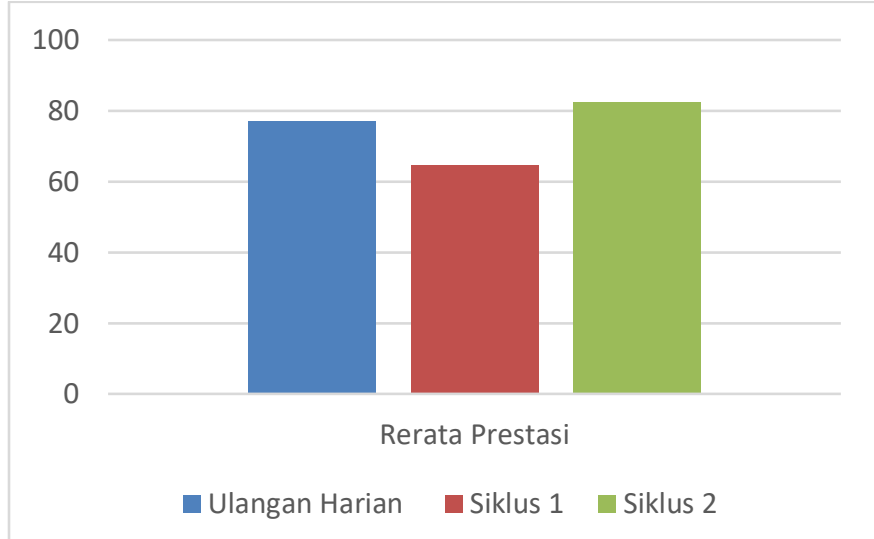

Gambar 1. Diagram Prestasi Belajar Siswa

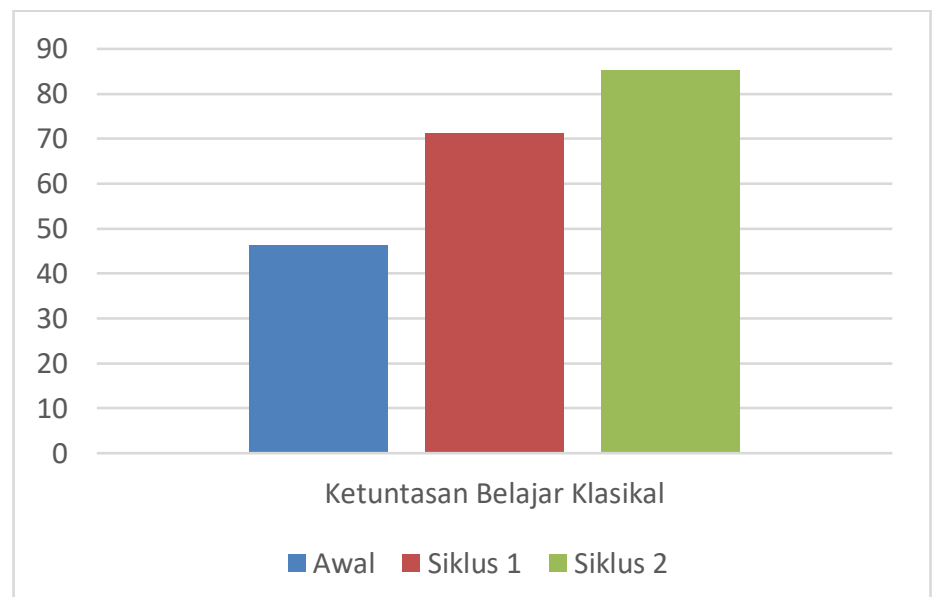

Gambar 2. Diagram Ketuntasan Belajar secara Klasikal

Berdasarkan tabel dan diagram di atas, mutu proses belajar sangat maju di tandai dengan perkembangan ketuntasan belajar yang mencapai $86,48 \%$ pada siklus 2 . Kemudian rata-rata prestasi belajar siswa juga naik dari 64,67 menjadi 82,37. Pada siklus 2 ini semua kelompok mendapat penghargaan, bahkan semua kelompok terjadi kenaikan penghargaan dengan 
lonjakan tinggi yaitu kelompok A, B, C, D, dan F dari TANPA PENGHARGAAN menjadi SUPER TEAM. Sedang kelompok E dan G dari TIDAK ADA PENGHARGAAN di siklus 1 menjadi kelompok GREAT TEAM pada siklus 2.

Pembelajaran PAI dan Budi Pekerti dengan metode Cooperative Learning dengan model STAD, pada umumnya positif. Berdasarkan wawancara informan dengan siswa, mereka merasa senang, aktivitas pembelajaran tidak tegang tetapi santai. Muncul keberanian siswa untuk mengemukakan pendapatnya. Rasa solidaritas tumbuh dengan baik.

\section{KESIMPULAN}

Berdasarkan hasil penelitian dan pembahasan, maka dapat di simpulkan bahwa : Pembelajaran PAI dan Budi Pekerti di kelas III SDN Singasari dengan menerapkan metode Cooperative Learning dengan model STAD dapat meningkatkan mutu proses pembelajaran. Hal ini di buktikan dengan semakin kooperatifnya para siswa dalam Pembelajaran PAI dan Budi Pekerti sejak siklus 1 hingga siklus 2. Di samping itu kooperatifnya siswa dalam pembelajaran juga berdampak pada prestasi belajar siswa. Ketuntasan belajar secara klasikal naik secara signifikan yaitu pada siklus 1 sebesar $7,14 \%$ menjadi $82,20 \%$ pada siklus 2 . Nilai rata-rata prestasi belajar naik yaitu pada siklus 1 sebesar 64,67 menjadi 82,37 pada siklus 2 . Siswa kelihatan senang dan berani mengemukakan pendapatnya.

\section{DAFTAR PUSTAKA}

Anita Lie, 2004. Mempraktikkan cooperatif learning di ruang-ruang kelas, Jakarta : Penerbit Grasindo.

Firdaus, M. 2016. Pengaruh Model Pembelajaran Kooperative Tipe Student Teams Achievement Divison (STAD), Jurnal Pendidikan Informatika dan Sains, Vol 5 (1):96104.

Kusuma, A. P. 2017. Implementasi Model Pembelajaran Student Teams Achievement Divison dan Team Assisted Individualization ditinjau dari Kemampuan Spasial Siswa. AlJabar: jurnal Pendidikan Matematika, 8(2), 135-144.

Mirhasli. 2021. Upaya Peningkatan Keaktifan dan Hasil Belajar Siswa melalui model Pembelajaran Student Teams Achievement Divison pada Materi Matriks, Jurnal Inovasi Strategi dan Model Pembelajaran, Vol (1): 215.

Nikmah, E.H., Fatchan, A., \& Wirahayu, Y. A. (2016). Model pembelajaran Student Teams Achievement Divison (stad), keaktifan dan hasil belajar siswa. Jurnal Pendidkan Geografi, 3(3), 1-17.

Slavin. 1999. Cooperative Learning theory, research, and practice. Second edition. London : Allynand Bacon

Trianto, 2007. Model-Model Pembelajaran Inovatif Berorientasi Konstruktivistik. Jakarta : Prestasi Pustaka 